\title{
The Comparison of Intraoperative Pressure Control and Volume Control Ventilation in Supine and Prone Positions: The Endless Debate
}

\author{
Intraoperatif Mekanik Ventilasyonda Supine ve Prone Pozisyonlarda Basınç \\ Kontrol ile Volüm Kontrol Modlarının Karşılaştırılması: Bitmeyen Tartışma, PCV \\ mi? VCV mi?
}

\author{
(D) Sinan Aşar ${ }^{1}$, (1) Furkan Tontu², (1) Gülay Aşık Eren³ \\ ${ }^{1}$ University of Health Sciences Turkey, Bakırköy Dr. Sadi Konuk Training and Research Hospital, Clinic of Anesthesiology and Reanimation, \\ Istanbul, Turkey \\ ${ }^{2}$ Ağrı Training and Research Hospital, Clinic of Anesthesiology and Reanimation, Ağrı, Turkey \\ ${ }^{3}$ Near East University Hospital, Clinic of Anesthesiology and Reanimation, Nicosia, TRNC
}

\begin{abstract}
Objective: Position (supine and prone) changes have their essential effects on respiratory mechanics and pulmonary perfusion in patients under general anesthesia. These effects on respiratory mechanics, arterial blood gas, and hemodynamic parameters in patients who underwent percutaneous nephrolithotomy operation were compared in pressure and volume control ventilation (VCV) modes.

Methods: This study prospectively evaluated 50 patients who underwent percutaneous nephrolithotomy. Patients were divided into groups of VCV and pressure control ventilation (PCV). Each group was divided further into two subgroups with supine and prone positions. General anesthesia was applied to all patients. Respiratory mechanics were recorded every $5 \mathrm{~min}$. Arterial blood gas samples were repeated at each position change. Hemodynamic and respiratory parameters were simultaneously recorded.

Results: Peak inspiratory pressure (Ppeak), plateau pressure (Pplato), and driving pressure (DP) of the VCV group were higher in the prone position than in the supine position. Ppeak, Pplato, and DP in the prone position were higher in the VCV group than the PCV group, and Horowitz ratio and compliance were lower. The Horowitz ratio of both groups was significantly higher in the prone than in the supine position.

Conclusion: Despite the advantages, the superiority of PCV to VCV cannot be mentioned at the present.
\end{abstract}

Keywords: Volume control, pressure control, prone, supine, driving pressure

\section{öz}

Amaç: Anestezi altındaki hastalarda pozisyon değişikliklerinin solunum mekanikleri ve pulmoner perfüzyon üzerine önemli etkileri mevcuttur. Perkütan nefrolitotomi operasyonu yapılan hastalara verilen pozisyonların (supine ve prone) solunum mekanikleri, arter kan gazı ve hemodinamik parametreler üzerine olan etkileri basınç kontrol ve volüm kontrol modlarında karşılaştııılmıştır.

Gereç ve Yöntem: Perkütan nefrolitotomi operasyonu planlanan 50 hasta prospektif olarak değerlendirildi. Hastalar volüm kontrol ve basınç kontrol grupları olarak ikiye ayrıldı. Her grup supine ve prone pozisyonları olacak şekilde iki subgruba ayrıldı. Tüm hastalara genel anestezi uygulandı. Solunum mekanikleri 5 dakika ara ile kaydedildi. Arter kan gazı örnekleri her pozisyon değişiminde tekrarlandı. Hemodinamik parametreler ve solunum parametreleri eş zamanlı olarak kaydedildi. Hasta ortalamaları alındıktan sonra gruplar Student's t-testi, grup içi parametreler ise Paired t-testi ile karşılaştırıldı.

Bulgular: Volüm kontrol grubunda prone pozisyonunda peak insipiratuar basıncı (Ppeak), plato basıncı (Pplato) ve sürücü basıncı (Driving Pressure: DP) supine pozisyonundaki değerlerden daha yüksek bulunmuștur. Her iki grubun prone pozisyon Horowitz oranı, supine pozisyon değerlerinden anlamlı derecede yüksek bulunmuştur. Prone pozisyonda, volüm kontrol grubunun basınç kontrol grubuna göre Ppeak, Pplato ve DP değerleri daha yüksek; kompliyans ve Horowitz oranı ise daha düşük hesaplanmıştır.

Address for Correspondence: Sinan Aşar, University of Health Sciences Turkey, Bakırköy Dr. Sadi Konuk Training and Research Hospital, Clinic of Anesthesiology and Reanimation, Istanbul, Turkey

Phone: +90 5442659844 E-mail: sinan.asaras@gmail.com ORCID ID: orcid.org/0000-0001-5787-5885

Cite as: Aşar S, Tontu F, Aşık Eren G. The Comparison of Intraoperative Pressure Control and Volume Control Ventilation in Supine and Prone Positions: The Endless Debate. Med J Bakirkoy 2021;17:412-419 
Sonuç: Horowitz oranı, hem volüm kontrol hem de basınç kontrol ventilasyonda, prone pozisyonda supine pozisyondan yüksek bulunmuştur. Basınç kontrol grubunda, volüm kontrol grubuna göre; daha düşük DP, daha yüksek akciğer kompliyansı ve daha yüksek Horowitz oranları hesaplanmıştır. Basınç kontrol modunun avantajlarına rağmen, günümüzde basınç kontrol ile volum kontrol modlarının birbirlerine olan üstünlüğünden bahsetmek söz konusu değildir.

Anahtar Kelimeler: Volüm kontrol, basınç kontrol, prone, supine, sürücü basınç

\section{INTRODUCTION}

Percutaneous nephrolithotomy is an invasive surgery that is performed in the supine and prone positions under general anesthesia (1). Depending on the surgical position, various changes occur in all body systems. As preferred by the surgical team, a position that will facilitate the surgical approach but will not endanger cardiovascular and pulmonary functions should be applied (2). Position changes have essential effects on respiratory mechanics and pulmonary perfusion in patients under general anesthesia (3). A $10 \%$ and $12.5 \%$ decreased vital capacity in the prone and supine positions were found, respectively (2).

Healthy people have decreased lung compliance during the prone position due to thoracal expansion restriction, decreased chest wall elasticity, obesity, neuromuscular blockers, and abdominal compression (4). However, prone positioning, which is also used to improve oxygenation in patients with acute respiratory distress syndrome (ARDS) in the intensive care unit, is a safe and most effective lungprotective ventilation strategy component that includes low positive end-expiratory pressure (PEEP), low tidal volume (TV), and low driving pressure (DP) (5).

Pulmonary blood flow and gas distribution differ according to the supine position in patients who are mechanically ventilated in the prone position (6). Thoracic wall movement is limited by compression. With decreased muscle tone due to neuromuscular blockers, the diaphragm is directed toward the cephalus by intra-abdominal pressure. The resulting changes in the lung volume and pulmonary blood flow differentiation affect the respiratory mechanics $(7,8)$.

Respiratory system compliance decreases by $17-30 \%$ when paralyzed patients under general anesthesia are turned to the prone position (9). However, some studies revealed no significant changes in the compliance when the appropriate position (with chest wall and pelvic supports) was given $(10,11)$. A significantly increased functional residual capacity is seen in the prone position, which can be explained by dependent alveoli reopening that tends to close in the supine position (12).

Better oxygenation in the prone position compared to the supine position is achieved by improving the ventilationperfusion ratio and eliminating lung compression by the heart. Thus, an increased ventilable lung is obtained (13).
Close monitoring of respiratory mechanics is vital in the operating room and the intensive care unit (14). Mechanical ventilation is life-saving; however, it causes ventilatorinduced lung injury (VILI) (15). Respiratory parameters, such as TV, DP, flow, respiratory rate, and PEEP, were associated with VILI (16). However, DP was considered the main mediator to cause VILI. Additionally, intraoperative high DP is associated with increased postoperative pulmonary complications (17).

This study compared the respiratory mechanics and blood gas parameters of patients who underwent percutaneous nephrolithotomy and were ventilated with volume control ventilation (VCV) or pressure control ventilation (PCV) in supine and prone positions.

\section{METHODS}

\section{Study Population}

This study was prospectively conducted in 50 patients who underwent percutaneous nephrolithotomy. Patients with the American Society of Anesthesiologists classification I-II, between the age of 18 and 65 years, without chronic obstructive pulmonary disease, diabetes, and cardiopulmonary diseases was included in the study. All patients underwent preoperative anesthetic evaluation.

\section{Study Design}

Patients were sequentially randomized into two groups, first from the VCV group and then from the PCV group. Vascular access was provided to patients after electrocardiogram, noninvasive blood pressure, and oxygen saturation $\left(\mathrm{SpO}_{2}\right)$ monitoring. At a rate of $2-4 \mathrm{~mL} / \mathrm{kg} / \mathrm{h}, 0.9 \% \mathrm{NaCl}$ infusion was started. Initial heart rate (HR), mean arterial pressure (MAP), and peripheral $\mathrm{SpO}_{2}$ were recorded as baseline values. Intravenously, propofol of $2 \mathrm{mg} / \mathrm{kg}$, fentanyl of $2 \mu \mathrm{g} / \mathrm{kg}$ for induction, and vecuronium of $0.1 \mathrm{mg} / \mathrm{kg}$ for neuromuscular blockage were given. After endotracheal intubation with a $7.5 \mathrm{~mm}$ inner diameter spiral tube, radial artery cannulation was performed. Balanced general anesthesia with sevoflurane of $1 \mathrm{MAC}$ and remifentanil was maintained. The VCV $(n=25)$ and PCV group $(n=25)$ were ventilated with Dräger Primus anesthetic machine (Lübeck, Germany). Ventilation parameters were constant with a respiratory rate of $12 / \mathrm{min}, \mathrm{PEEP}$ of $5 \mathrm{~cm} \mathrm{H}_{2} \mathrm{O}$, and inspiration-expiration rate of 1:2. These settings remained since the end-tidal carbon 
dioxide $\left(\mathrm{EtCO}_{2}\right)$ was in the range of 30-35 in all patients. At the beginning of the operation, all patients were ventilated with a TV of 6-8 $\mathrm{mL} / \mathrm{kg}$, and the DP is adjusted to provide this TV in the PCV group. Respiratory and hemodynamic parameters of all patients were recorded at $0,5,10,15,20$, 25 , and 30 min with 5 -min intervals in the supine period after induction. Similarly, $5 \mathrm{~min}$ after the patient was turned to the prone position, the data were recorded at 5, 10,15, 20, $25 \mathrm{t}, 30$, and $35 \mathrm{~min}$ with 5 -min intervals. Arterial blood gas samples were taken at the $30^{\text {th }}$ min in the supine position and the $35^{\text {th }}$ min in the prone position.

Thoracal gel supports were placed on both sides of the chest during prone positioning. After the patients were turned to the supine position at the end of the surgery, inhalation agents were stopped. Atropine of $0.01 \mathrm{mg} /$ $\mathrm{kg}$ and neostigmine of $0.03 \mathrm{mg} / \mathrm{kg}$ were administered to eliminate residual neuromuscular blockade after spontaneous breathing started. Patients were extubated when spontaneous breathing was sufficient. All patients were hemodynamically stable, without complications.

Compliance, peak inspiratory pressure (Ppeak), plateau pressure (Pplato), DP, ETCO $2^{\prime} \mathrm{HR}, \mathrm{MAP}, \mathrm{pH}$, partial arterial carbon dioxide pressure $\left(\mathrm{PaCO}_{2}\right)$, bicarbonate $\left(\mathrm{HCO}_{3}\right)$, and partial arterial oxygen pressure $\left(\mathrm{PaO}_{2}\right)$ parameters were recorded as excel file.

The mean values of all data in supine and prone positions were recorded for statistical analyses.

\section{Calculation of DP and Compliance}

The gas flow is constant in VCV and 5\% pause time (Tpause) is set at the end of inspiration, thus Pplato and compliance are automatically calculated by the ventilator and screen display. In PCV, the airway pressure is considered constant from the beginning to the end of inspiration. Therefore, Ppeak and alveolar pressure (Pplato) are calculated as equal (18-20).

The presence of auto-PEEP was evaluated with the expiratory hold maneuver. However, auto-PEEP was not detected in our patients (Auto - PEEP $=$ PEEPtotal - PEEPset). Since no autoPEEP exists, DP is calculated as (DP) $=$ Ppeak - PEEP, and compliance is calculated as $(C)=$ Tve $\div($ Ppeak $-P E E P)$ in PCV.

\section{Sample Size Calculation}

A pilot study was conducted with five patients to determine the number of patients to be included in the study. The comparison of VCV and PCV in the prone position determined the DP difference as the primary outcome. In the prone position, DP was calculated as $13 \pm 2 \mathrm{cmH}_{2} \mathrm{O}$ in VCV and $11 \pm 2 \mathrm{cmH}_{2} \mathrm{O}$ in PCV. The sample size was calculated as at least 23 patients per group based on a pilot study (power=95\%; $\alpha=0.05$ ) (G*Power version 3.1.9.4, Germany).

\section{Statistical Analyses}

The gender distribution of the groups was compared using the Chi-square test. Demographic data (age, height, and weight), arterial blood gas, and respiratory parameters of the groups were homogeneous in the Shapiro-Wilk test and were evaluated with the Student's t-test. Subgroup comparisons were made with the paired t-test. The mean and standard deviation (SD) values for each parameter were used for statistical representation. Results were evaluated at the significance level of $p<0.05$. Statistical analyzes were made with Number Cruncher Statistical System 2007 Statistical Software (Utah, USA).

\section{RESULTS}

No statistical difference was found between gender distribution and mean \pm SD values of age, height, predictive bodyweight of the VCV and PCV groups (Table 1).

A statistically significant difference was observed between the mean values of Ppeak, $\mathrm{TV}, \mathrm{PaO}_{2} / \mathrm{FiO}_{2}$ in the supine position of the VCV and PCV groups, whereas no statistically significant difference between the mean values of Pplato, TV, DP, compliance, ETCO $2^{\prime} \mathrm{PaCO}_{2^{\prime}} \mathrm{HCO}_{3^{\prime}} \mathrm{pH}, \mathrm{HR}$, and MAP.

A statistically significant difference was observed between the mean values of Ppeak, Pplato, DP, TV, compliance, $\mathrm{PaO}_{2} / \mathrm{FiO}_{2}$ in the prone position of the VCV and PCV groups, whereas no statistically significant difference between the mean values of $\mathrm{ETCO}_{2}, \mathrm{PaCO}_{2^{\prime}} \mathrm{HCO}_{3^{\prime}}, \mathrm{pH}, \mathrm{HR}$, and MAP.

The mean $\pm \mathrm{SD}$ of the above-mentioned respiratory parameters of the VCV and PCV groups in the supine and prone positions are shown in Table 2.

In the VCV group, Ppeak, Pplato, $\mathrm{DP}, \mathrm{PaO}_{2}$ and $\mathrm{PaO}_{2} / \mathrm{FiO}_{2}$ values were statistically significantly higher, and compliance values were significantly lower in the prone position than the supine position. However, no statistically significant difference was observed between $\mathrm{ETCO}_{2^{\prime}}, \mathrm{PaCO}_{2^{\prime}}, \mathrm{HCO}_{3^{\prime}}$ and $\mathrm{pH}$ values.

\begin{tabular}{|c|c|c|c|}
\hline & VCV group & PCV group & $p$ \\
\hline Female (\%) & 11 (11.44\%) & $9(9.36 \%)$ & 0.24 \\
\hline Age, years (mean $\pm S D$ ) & $44.2 \pm 14.32$ & $39.84 \pm 13.56$ & 0.24 \\
\hline Height, cm (mean \pm SD) & 173.086 .52 & 172.045 .22 & 0.5 \\
\hline PBW, kg (mean \pm SD) & $76.52 \pm 12.53$ & $71.52 \pm 7.07$ & 0.9 \\
\hline
\end{tabular}

PBW: Predictive body weight, VCV: Volume control ventilation PCV:

Pressure control ventilation SD: Standard deviation 
The mean \pm SD values of the respiratory parameters in the supine and prone positions of the VCV group are shown in Table 3.

In the PCV group, $\mathrm{PaO}_{2}, \mathrm{PaO}_{2} / \mathrm{FiO}_{2}$ values were statistically significantly higher, and TV and compliance values were significantly lower in the prone position than the supine position. However, no statistically significant difference was observed between Ppeak, Pplato, and DP values.

The mean \pm SD values of respiratory parameters in the supine and prone positions of the PCV group are shown in Table 4.

\section{DISCUSSION}

PCV and VCV have been compared for a long time (21-24). Our study re-discussed this issue with current topics, such as DP, under the guidance of previous studies.

The mean $\mathrm{PaO}_{2}$ values of the PCV group were higher than the VCV group in supine and prone positions. Studies show that PCV provides better $\mathrm{PaO}_{2}$ values in supine and prone positions than VCV mode (24-29).
No significant difference was found between the $\mathrm{PaCO}_{2}$ values between the PCV and VCV groups in supine and prone positions. Additionally, a recent meta-analysis reported no difference in $\mathrm{PaCO}_{2}$ values between the VCV and PCV groups in patients who had elective surgery in the supine position (24).

In VCV and PCV groups, mean $\mathrm{PaO}_{2}$ values were statistically significantly lower in the supine than in the prone position. In the prone position, significantly increased $\mathrm{PaO}_{2}$ values have been attributed to the reduced dependent lung areas and the lesser gravitational effect of the heart and great vessels on the lung $(25,26,30,31)$. Thus, a better perfusion/ ventilation ratio is obtained (32). Additionally, increased functional residual capacity and secretion mobilization also contribute to this improvement (26). Many studies have indicated that the prone position positively affects the arterial blood gas parameters (33-35). Our study revealed no difference between the $\mathrm{PCO}_{2}$ values in position changes in both ventilation modes. Previous studies have shown that $\mathrm{PaCO}_{2}$ values in the prone position are equal or lower than in the supine position (33-35).

Table 2. The comparison of patients in the VCV and PCV groups with the Student's t-test for arterial blood gas results, hemodynamic, and respiratory parameters in the supine and prone positions

\begin{tabular}{|c|c|c|c|c|}
\hline $\operatorname{VCV}(n=25)$ vs. PCV $(n=25)$ & VCV supine vs. PCV supine & $\mathrm{p}$ & VCV prone vs. PCV prone & $\mathrm{p}$ \\
\hline- & mean $\pm S D$ vs. mean $\pm S D$ & - & mean $\pm \mathrm{SD}$ vs. mean $\pm \mathrm{SD}$ & - \\
\hline Pplato, $\mathrm{cm} \mathrm{H}_{2} \mathrm{O}$ & $15.3 \pm 1.9$ vs. $15.9 \pm 1.1$ & $>0.05$ & $19.3 \pm 1.9$ vs. $15.9 \pm 1.1$ & 0.0001 \\
\hline Ppeak, $\mathrm{cm} \mathrm{H}_{2} \mathrm{O}$ & $17.2 \pm 1.7$ vs. $15.9 \pm 1.1$ & 0.01 & $21.7 \pm 1.9$ vs. $15.9 \pm 1.4$ & 0.001 \\
\hline $\mathrm{DP}, \mathrm{cm} \mathrm{H}_{2} \mathrm{O}$ & $10.1 \pm 1.8$ vs. $10.9 \pm 1.0$ & $>0.05$ & $13.3 \pm 1.8$ vs. $10.5 \pm 1.1$ & 0.0001 \\
\hline PEEP, $\mathrm{cm} \mathrm{H}_{2} \mathrm{O}$ & $4.7 \pm 0.1$ vs. $4.9 \pm 0.1$ & $>0.05$ & $4.8 \pm 0.1$ vs. $4.9 \pm 0.1$ & $>0.05$ \\
\hline TVe, mL & $598 \pm 50$ vs. $605 \pm 60$ & $>0.05$ & $570 \pm 40$ vs. $516 \pm 62$ & 0.001 \\
\hline RR, per minute & 12 vs. 12 & $>0.05$ & 12 vs. 12 & $>0.05$ \\
\hline $\mathrm{C}, \mathrm{mL} / \mathrm{cm} \mathrm{H}_{2} \mathrm{O}$ & $60.6 \pm 8.2$ vs. $61.2 \pm 6.9$ & $>0.05$ & $40.0 \pm 6.2$ vs. $46.0 \pm 5.6$ & 0.001 \\
\hline $\mathrm{ETCO}_{2}, \mathrm{meq} / \mathrm{L}$ & $30 \pm 5$ vs. $29 \pm 2$ & $>0.05$ & $28 \pm 5$ vs. $28 \pm 2$ & $>0.05$ \\
\hline $\mathrm{pH}$ & $7.45 \pm 0.05$ vs. $7.44 \pm 0.05$ & $>0.05$ & $7.46 \pm 0.06$ vs. $7.42 \pm 0.04$ & $>0.05$ \\
\hline $\mathrm{HCO}_{3}, \mathrm{meq} / \mathrm{L}$ & $25 \pm 2.1$ vs. $24.1 \pm 2.2$ & $>0.05$ & $23.4 \pm 2.1$ vs. $23.1 \pm 2.7$ & $>0.05$ \\
\hline $\mathrm{PCO}_{2}, \mathrm{mmHg}$ & $35 \pm 5$ vs. $34 \pm 5$ & $>0.05$ & $33 \pm 6$ vs. $34 \pm 5)$ & $>0.05$ \\
\hline $\mathrm{PaO}_{2}, \mathrm{mmHg}$ & $223 \pm 53$ vs. $281 \pm 66$ & 0.001 & $248 \pm 35$ vs. $301 \pm 53$ & 0.0001 \\
\hline $\mathrm{FiO}_{2}, \%$ & 50 vs. 50 & 0.05 & 50 vs. 50 & $>0.05$ \\
\hline $\mathrm{PaO}_{2} / \mathrm{FiO}_{2}$ & $446 \pm 106$ vs. $562 \pm 132$ & 0.001 & $496 \pm 70$ vs. $602 \pm 108$ & 0.0001 \\
\hline HR, per minute & $75 \pm 9$ vs. $76 \pm 7$ & $>0.05$ & $62 \pm 6$ vs. $63 \pm 8$ & $>0.05$ \\
\hline $\mathrm{MAP}, \mathrm{mmHg}$ & $81 \pm 5$ vs. $83 \pm 7$ & $>0.05$ & $87 \pm 7$ vs. $93 \pm 9$ & $>0.05$ \\
\hline
\end{tabular}


Table 3. The comparison of arterial blood gas and respiratory parameters of the VCV group in the supine and prone positions with the paired t-test

\begin{tabular}{|c|c|c|c|}
\hline VCV group $(n=25)$ & $\begin{array}{l}\text { a) Supine } \\
\text { position }\end{array}$ & $\begin{array}{l}\text { b) Prone } \\
\text { position }\end{array}$ & $\mathbf{p}$ \\
\hline- & mean $\pm S D$ & mean $\pm S D$ & - \\
\hline Pplato, $\mathrm{cmH}_{2} \mathrm{O}$ & $15 \pm 1.9$ & $(19 \pm 1.9)$ & $p<0.0001$ \\
\hline Ppeak, $\mathrm{cmH}_{2} \mathrm{O}$ & $17.2 \pm 1.7$ & $(21.7 \pm 1.9)$ & $p<0.0001$ \\
\hline PEEP, $\mathrm{cmH}_{2} \mathrm{O}$ & $4.7 \pm 0.1$ & $4.8 \pm 0.1$ & $p \geq 0.05$ \\
\hline $\mathrm{DP}, \mathrm{cmH}_{2} \mathrm{O}$ & $10.1 \pm 1.8$ & $13.3 \pm 1.8$ & $p<0.0001$ \\
\hline Tidal Volume (TV) mL & $598 \pm 50$ & $570 \pm 40$ & $p<0.01$ \\
\hline $\mathrm{RR}, 1 / \mathrm{min}$ & 12 & 12 & $p \geq 0.05$ \\
\hline $\mathrm{C}, \mathrm{mL} / \mathrm{cmH}_{2} \mathrm{O}$ & $60.6 \pm 9.2$ & $(39.9 \pm 6.2)$ & $p<0.0001$ \\
\hline $\mathrm{ETCO}_{2^{\prime}}(\mathrm{meq} / \mathrm{L})$ & $30 \pm 7$ & $30 \pm 5$ & $p \geq 0.05$ \\
\hline $\mathrm{pH}$ & $7.45 \pm 0.05$ & $7.46 \pm 0.06$ & $p \geq 0.05$ \\
\hline $\mathrm{HCO}_{3^{\prime}}($ meq/L) & $25 \pm 2.0$ & $23 \pm 2.1$ & $p \geq 0.05$ \\
\hline $\mathrm{PCO}_{2^{\prime}}(\mathrm{mmHg})$ & $35 . \pm 5$ & $34 \pm 6$ & $p \geq 0.05$ \\
\hline $\mathrm{PaO}_{2^{\prime}}(\mathrm{mmHg})$ & $223 \pm 53$ & $248 \pm 35$ & $\mathrm{p}<0.001$ \\
\hline $\mathrm{FiO}_{2^{\prime}}(\%)$ & 50 & 50 & $p \geq 0.05$ \\
\hline $\mathrm{PaO}_{2} / \mathrm{FiO}_{2}$ & $446 \pm 106$ & $496 \pm 70$ & $\mathrm{p}<0.001$ \\
\hline \multicolumn{4}{|c|}{$\begin{array}{l}\text { C: Lung compliance, PEEP: Positive end-expiratory pressure, Ppeak: Peak } \\
\text { Inspiratory pressure, DP: Driver pressure, TVe: Expiratory tidal volume, } \\
\text { Pplato: Plateau pressure, ETCO } \mathrm{CO}_{2} \text { : End-tidal carbon dioxide, } \mathrm{HR} \text { : Heart } \\
\text { rate, MAP: Mean arterial pressure, } \mathrm{PaCO}_{2}: \text { Partial arterial carbon dioxide } \\
\text { pressure, } \mathrm{PaO} \mathrm{O}_{2}: \text { Partial arterial oxygen pressure, } \mathrm{HCO}_{3}: \text { Bicarbonate, VCV: } \\
\text { Volume control ventilation PCV: Pressure control ventilation SD: Standard } \\
\text { deviation }\end{array}$} \\
\hline
\end{tabular}

At the beginning of the operation, despite higher TV in the PCV group, no significant difference was found between the Pplato values in the supine position of the PCV and VCV groups. However, after the patient was turned to the prone position, the Pplato values of the PCV group were lower than the VCV group, although the other set of respiratory parameters (DP in PCV and TV in VCV) were constant. Similarly, Ppeak values of the PCV group were also lower in both positions. Studies report that Ppeak and Pplato values of the VCV group in the prone position are equal or higher than in the supine position $(10,26,36)$. Another study that ventilated patients with VCV after anesthesia induction and pneumoperitoneum revealed decreased Pplato values when the ventilation mode was changed to PCV after 40 min (35). A meta-analysis reported lower intraoperative Ppeak and Pplato values in PCV (29)

The lower Ppeak and Pplato values in the PCV group were attributed to the different gas flow patterns between the two groups (35). Therefore, no difference was found between the $D P$ values of the VCV and PCV groups in the supine position but a significant difference in the prone position. Similarly,
Table 4. Arterial blood gas and respiratory parameters of the PCV group in the supine and prone positions were compared with the paired t-test

\begin{tabular}{|c|c|c|c|}
\hline PCV group $(n=25)$ & $\begin{array}{l}\text { a) Supine } \\
\text { position }\end{array}$ & $\begin{array}{l}\text { b) Prone } \\
\text { position }\end{array}$ & $p$ \\
\hline & mean $\pm S D$ & mean $\pm S D$ & - \\
\hline Pplato, $\mathrm{cmH}_{2} \mathrm{O}$ & $15.9 \pm 1.1$ & $15.9 \pm 1.1$ & $p \geq 0.05$ \\
\hline Ppeak, $\mathrm{cmH}_{2} \mathrm{O}$ & $15.9 \pm 1.1$ & $15.9 \pm 1.1$ & $p \geq 0.05$ \\
\hline PEEP, $\mathrm{cmH}_{2} \mathrm{O}$ & $4.8 \pm 0.1$ & $4.9 \pm 0.1$ & $p \geq 0.05$ \\
\hline $\mathrm{DP}, \mathrm{cmH}_{2} \mathrm{O}$ & $10.9 \pm 1.0$ & $10.9 \pm 1.0$ & $p \geq 0.05$ \\
\hline Tidal Volume $(\Delta \mathrm{V}) . \mathrm{mL}$ & $630 \pm 79$ & $(516 \pm 62)$ & $p<0.0001$ \\
\hline $\mathrm{RR}, 1 / \mathrm{min}$ & 12 & 12 & $p \geq 0.05$ \\
\hline C, $\mathrm{mL} / \mathrm{cmH}_{2} \mathrm{O}$ & $64.3 \pm 6.9$ & $(46.0 \pm 5.6)$ & $p<0.0001$ \\
\hline $\mathrm{ETCO}_{2^{\prime}}(\mathrm{meq} / \mathrm{L})$ & $29 \pm 2$ & $(28 \pm 2)$ & $p \geq 0.05$ \\
\hline $\mathrm{PH}$ & $7.44 \pm 0.05$ & $7.43 \pm 0.04$ & $p \geq 0.05$ \\
\hline $\mathrm{HCO}_{3^{\prime}}(\mathrm{meq} / \mathrm{L})$ & $24.1 \pm 2.1$ & $23.1 \pm 2.7$ & $p \geq 0.05$ \\
\hline $\mathrm{PCO}_{2^{\prime}}(\mathrm{mmHg})$ & $34 \pm 5$ & $34 \pm 5$ & $33 \pm 5$ \\
\hline $\mathrm{PaO}_{2^{\prime}}(\mathrm{mmHg})$ & $281 \pm 66$ & $(301 \pm 53)$ & $p<0.01$ \\
\hline $\mathrm{FiO}_{2^{\prime}}(\%)$ & 50 & 50 & $p \geq 0.05$ \\
\hline $\mathrm{PaO}_{2} / \mathrm{FiO}_{2}$ & $562 \pm 132$ & $(602 \pm 108)$ & $\mathrm{p}<0.01$ \\
\hline
\end{tabular}

C: Lung compliance, PEEP: Positive end-expiratory pressure, Ppeak: Peak Inspiratory pressure, DP: Driver pressure, TVe: Expiratory tidal volume, Pplato: Plateau pressure, ETCO : End-tidal carbon dioxide, HR: Heart rate, MAP: Mean arterial pressure, $\mathrm{PaCO}_{2}$ : Partial arterial carbon dioxide pressure $\mathrm{PaO}_{2}$ : Partial arterial oxygen pressure, $\mathrm{HCO}_{3}$ : Bicarbonate, $\mathrm{VCV}$ : Volume control ventilation PCV: Pressure control ventilation SD: Standard deviation

DP values of the VCV group were significantly different between positions. The DP is constant in both positions in $\mathrm{PCV}$, thus homogeneous ventilation of the alveoli with different time constants is ensured and prevented excessive bronchoalveolar unit stretching (26,35-37).

No difference was found between the compliance of the VCV and PCV groups in the supine position. However, when the patients were turned to the prone position without changing their respiratory settings, the compliance was significantly higher in the PCV group than the VCV group. The compliance of the VCV and PCV groups in the supine position was statistically significantly higher than in the prone position. The reduced compliance of the VCV group when patients are turned to the prone position is thought to be due to the increased Ppeak and Pplato. Contrarily, Ppeak and Pplato are constant in PCV, thus the reduced compliance is due to the decreased TV. Reduced lung compliance in the prone position is due to the increased abdominal pressure to the thorax due to neuromuscular blockers, thoracal movement restriction, and chest wall compression by the support materials $(26,35,37)$. The study of Sen et al. (38) 
in percutaneous nephrolithotomy patients compared the PCV and VCV modes in the prone and supine positions, and compliance was found to be lower in both modes in the prone position. The compliance of the PCV group in the prone position was found to be higher than the VCV group (38). The compliance decreases from supine to the prone position by approximately $17 \%$ to $30 \%$ (9). However, studies report that compliance in the prone position will not change with correctly placed thoracal and pelvic supports $(10,11)$. Compliance was observed to significantly increase when switching from VCV to PCV after anesthesia induction (35). In patients who underwent laparoscopic gynecological surgery, lung compliance was higher in PCV than VCV (39). Changes in compliance are due to the gas flow pattern. The decreasing flow pattern in the PCV is argued to reduce lung tension. However, changes in compliance while isovolumetric depend not only on the elastic properties of the respiratory system but also on the resistive component of the airway and endotracheal tube $(26,35)$.

Respiratory dynamic changes in the prone position mentioned above are due to the need for a higher DP to reach the set TV in VCV and the lower TV to reach the set DP in PCV.

High DP was strongly associated with VILI and mortality (40). Additionally, high DP on the first day of mechanical ventilation is a risk factor for ARDS development later on (41) and is also associated with postoperative pulmonary complications (17). Therefore, obtaining a better gas exchange with lower DP gave PCV an advantage over VCV. Compared to the VCV group, the PCV group had lower DP and better gas exchange. However, this advantage of PCV has recently become controversial (42) since reaching inspiratory pressure (DP) in a short time interval (T-slope) with the highly variable gas flow in PCV can have a damaging effect. These theoretical concerns regarding the PCV should be seen as worthy of investigation.

Postoperative pulmonary complications develop in 5\%$33 \%$ of patients. These complications were shown to reduce with lung-protective ventilation. For lung-protective ventilation in the surgical patient, an international expert panel recommends that Cdyn, DP, and Pplato should be monitored on all mechanically controlled ventilated patients, and currently, a preferred specific ventilation mode is not recommended, as studies are reporting conflicting results (43).

Our study has some limitations. First, airway resistance parameters were not compared between ventilation modes since inspiratory resistance values in PCV were not automatically calculated by the ventilator, and we did not have the opportunity to calculate with the least-square fit method (44). Second, the effects of both ventilation modes and position changes on advanced hemodynamic parameters (central venous pressure, cardiac output, systemic vascular resistance, and lung water) have not been studied. Third, neuromuscular blockade monitoring could not be performed.

\section{CONCLUSION}

Prone position was beneficial as it increased oxygenation in both the VCV and PCV groups without causing any adverse effects on hemodynamic and respiratory mechanics. The PCV group had better respiratory mechanics (lower DP and Pplato) and blood gas parameters (higher $\mathrm{PaO}_{2}$ ) than the VCV group in the prone position. However, today, the superiority of PCV and VCV over each other cannot be mentioned.

\section{ACKNOWLEDGMENTS}

The authors would like to thank Oya Hergünsel for her valuable support.

\section{ETHICS}

Ethics Committee Approval: Ethical approval was obtained from University of Healht Sciences Turkey, Bakırköy Dr. Sadi Konuk Training and Research Hospital Clinical Research Ethics Committee (code: 2009/106, date: 06.18.2009). The research conforms to the provisions of the Declaration of Helsinki in 1995 (as revised in Brazil 2013).

Informed Consent: Written consent was obtained from all patients.

\section{Authorship Contributions}

Surgical and Medical Practices: S.A., Concept: S.A., G.A.E., Design: S.A., F.T., G.A.E., Data Collection or Processing: S.A., Analysis or Interpretation: S.A., F.T., Literature Search: S.A., F.T., Writing: S.A., F.T., G.A.E.

Conflict of Interest: No conflict of interest was declared by the authors.

Financial Disclosure: The authors declared that this study received no financial support.

\section{References}

1. Miano R, Scoffone C, De Nunzio C, Germani S, Cracco C, Usai $P$, et al. Position: prone or supine is the issue of percutaneous nephrolithotomy. J Endourol 2010;24:931-8.

2. Richter $T$, Bellani G, Scott Harris R, Vidal Melo MF, Winkler T, Venegas JG, et al. Effect of prone position on regional shunt, aeration, and perfusion in experimental acute lung injury. Am J Respir Crit Care Med 2005;172:480-7. 
3. Tanskanen P, Kyttä J, Randell T. The effect of patient positioning on dynamic lung compliance. Acta Anaesthesiol Scand 1997;41:602-6.

4. Halbertsma F, Van der Hoeven JG. Lung recruitment during mechanical positive pressure ventilation in the PICU: what can be learned from the literature? Anaesthesia 2005;60:779-90.

5. Guérin C, Albert RK, Beitler J, Gattinoni L, Jaber S, et al. Prone position in ARDS patients: why, when, how and for whom. Intensive Care Med 2020;46:2385-96.

6. Johannigman JA, Davis K Jr, Miller SL, Campbell RS, Luchette FA, Frame SB, et al. Prone positioning and inhaled nitric oxide: synergistic therapies for acute respiratory distress syndrome. J Trauma Acute Care Surg 2001;50:595-6.

7. Damia G, Mascheroni D, Croci M, Tarenzi L. Perioperative changes in functional residual capacity in morbidly obese patients. $\mathrm{Br} \mathrm{J}$ Anaesth 988;60:574-8.

8. Pelosi P, Croci M, Calappi E, Mulazzi D, Cerisara M, Vercesi P, et al. Prone positioning improves pulmonary function in obese patients during general anesthesia. Anesth Analg 1996;83:578-83.

9. Soro M, García-Pérez ML, Belda FJ, Ferrandis R, Aguilar G, Tusman $G$, et al. Effects of prone position on alveolar dead space and gas exchange during general anaesthesia in surgery of long duration. Eur J Anaesthesiol 2007;24:431-7.

10. Pelosi P, Croci M, Calappi E, Cerisara M, Mulazzi D, Vicardi $P$, et al. The prone positioning during general anesthesia minimally affects respiratory mechanics while improving functional residual capacity and increasing oxygen tension. Anesth Analg 1995;80:955-60.

11. Palmon SC, Kirsch JR, Depper JA, Toung TJ. The effect of the prone position on pulmonary mechanics is frame-dependent. Anesth Analg 1998;87:1175-80.

12. Hedenstierna G, Tokics L, Strandberg $\AA$, Lundquist H, Brismar B. Correlation of gas exchange impairment to development of atelectasis during anaesthesia and muscle paralysis. Acta Anaesthesiol Scand 1986;30:183-91.

13. Glenny RW, Lamm W, Albert RK, Robertson HT. Gravity is a minor determinant of pulmonary blood flow distribution. J Appl Physiol 1991;71:620-9

14. Ball L, Costantino F, Fiorito M, Amodio S, Pelosi P. Respiratory mechanics during general anaesthesia. Ann Transl Med 2018;6:379.

15. Slutsky AS, Ranieri VM. Ventilator-induced lung injury. N Engl J 2013;369:2126-36.

16. Hotchkiss JR Jr, Blanch L, Murias G, Adams AB, Olson DA, Wangensteen $O D$, et al. Effects of decreased respiratory frequency on ventilator-induced lung injury. Am J Respir Crit Care Med 2000;161:463-8.

17. Neto AS, Hemmes SN, Barbas CS, Beiderlinden M, FernandezBustamante A, Futier E, et al. Association between driving pressure and development of postoperative pulmonary complications in patients undergoing mechanical ventilation for general anaesthesia: a meta-analysis of individual patient data. Lancet Respir Med 2016;4:272-80.

18. van der Meijden S, Molenaar M, Somhorst P, Schoe A. Calculating mechanical power for pressure-controlled ventilation. Intensive Care Med 2019;45:1495-7.

19. Silva PL, Ball L, Rocco PRM, Pelosi P. Power to mechanical power to minimize ventilator-induced lung injury? Intensive Care Med Exp 2019;7(Suppl 1):38.

20. Ashworth L, Norisue Y, Koster M, Anderson J, Takada J, Ebisu H. Clinical management of pressure control ventilation: An algorithmic method of patient ventilatory management to address "forgotten but important variables". J Crit Care 2018;43:169-82.

21. Campbell RS, Davis BR. Pressure-controlled versus volumecontrolled ventilation: does it matter? Respir Care 2002;47:416-26.
22. Chacko B, Peter JV, Tharyan P, John G, Jeyaseelan L. Pressurecontrolled versus volume-controlled ventilation for acute respiratory failure due to acute lung injury (ALI) or acute respiratory distress syndrome (ARDS). Cochrane Database Syst Rev 2015;1:CD008807.

23. Lee JM, Lee SK, Kim KM, Kim YJ, Park EY. Comparison of volumecontrolled ventilation mode and pressure-controlled ventilation with volume-guaranteed mode in the prone position during lumbar spine surgery. BMC Anesthesiol 2019;19:133.

24. Schick V, Dusse F, Eckardt R, Kerkhoff S, Commotio S, Hinkelbein $\mathrm{J}$, et al. Comparison of Volume-Guaranteed or -Targeted, PressureControlled Ventilation with Volume-Controlled Ventilation during Elective Surgery: A Systematic Review and Meta-Analysis. J Clin Med 2021;10:1276.

25. Cakar N, der Kloot TV, Youngblood M, Adams A, Nahum A. Oxygenation response to a recruitment maneuver during supine and prone positions in an oleic acid-induced lung injury model. Am J Respir Crit Care Med 2000;161:1949-56.

26. Manna EM, Ibraheim OA, Samarkandi AH, Alotaibi WM, Elwatidy $\mathrm{SM}$. The effect of prone position on respiratory mechanics during spinal surgery. Middle East J Anaesthesiol 2005;18:623-30.

27. Lee JM, Lee SK, Rhim CC, Seo KH, Han M, Kim SY, et al. Comparison of volume-controlled, pressure-controlled, and pressure-controlled volume-guaranteed ventilation during robot-assisted laparoscopic gynecologic surgery in the Trendelenburg position. Int J Med Sci 2020;17:2728-34.

28. Kim MS, Soh S, Kim SY, Song MS, Park JH. Comparisons of Pressure-controlled Ventilation with Volume Guarantee and Volume-controlled 1:1 Equal Ratio Ventilation on Oxygenation and Respiratory Mechanics during Robot-assisted Laparoscopic Radical Prostatectomy: a Randomized-controlled Trial. Int J Med Sci 2018;15:1522-9.

29. Jiang J, Li B, Kang N, Wu A, Yue Y. Pressure-Controlled Versus Volume-Controlled Ventilation for Surgical Patients: A Systematic Review and Meta-analysis. J Cardiothorac Vasc Anesth 2016;30:50114.

30. Mezidi M, Guérin C. Effects of patient positioning on respiratory mechanics in mechanically ventilated ICU patients. Ann TransI Med 2018;6:384

31. Scholten EL, Beitler JR, Prisk GK, Malhotra A. Treatment of ARDS With Prone Positioning. Chest 2017;151:215-24.

32. Mure $M$, Domino KB, Lindahl SG, Hlastala MP, Altemeier WA, Glenny RW. Regional ventilation-perfusion distribution is more uniform in the prone position. J Appl Physiol (1985) 2000;88:107683.

33. Magi E, Multari G, Recine C, Barberio O, Becattini G, Tellini A. [Difference between arterial and end-tidal carbon dioxide tension during surgery of lumbar herniated disk in general anesthesia]. Minerva Anestesiol 1994;60:381-6.

34. Wahba RW, Tessler MJ, Kardash KJ. Carbon dioxide tensions during anesthesia in the prone position. Anesth Analg 1998;86:6689.

35. Balick-Weber CC, Nicolas $P$, Hedreville-Montout $M$, Blanchet $P$, Stéphan F. Respiratory and haemodynamic effects of volumecontrolled vs pressure-controlled ventilation during laparoscopy: a cross-over study with echocardiographic assessment. Br J Anaesth 2007;99:429-35

36. De Baerdemaeker LE, Van der Herten C, Gillardin JM, Pattyn P, Mortier EP, Szegedi LL. Comparison of volume-controlled and pressure-controlled ventilation during laparoscopic gastric banding in morbidly obese patients. Obes Surg 2008;18:680-5.

37. Cox RG, Ewen A, Bart BB. The prone position is associated with a decrease in respiratory system compliance in healthy anaesthetized infants. Paediatr Anaesth 2001;11:291-6. 
38. Sen O, Bakan M, Umutoglu T, Aydın N, Toptas M, Akkoc I. Effects of pressure-controlled and volume-controlled ventilation on respiratory mechanics and systemic stress response during prone position. Springerplus 2016;5:1761.

39. Oğurlu $M$, Küçük $M$, Bilgin $F$, Sizlan $A$, Yanarateş $O$, Eksert $S$, et al. Pressure-controlled vs volume-controlled ventilation during laparoscopic gynecologic surgery. J Minim Invasive Gynecol 2010;17:295-300.

40. Amato MB, Meade MO, Slutsky AS, Brochard L, Costa EL, Schoenfeld DA, et al. Driving pressure and survival in the acute respiratory distress syndrome. N Engl J Med 2015;372:747-55.

41. Roca O, Peñuelas O, Muriel A, García-de-Acilu M, Laborda C Sacanell J, et al. Driving Pressure Is a Risk Factor for ARDS in
Mechanically Ventilated Subjects Without ARDS. Respir Care 2021;66:1505-13.

42. Marini JJ, Crooke PS, Gattinoni L. Intra-cycle power: is the flow profile a neglected component of lung protection? Intensive Care Med 2021;47:609-11.

43. Young CC, Harris EM, Vacchiano C, Bodnar S, Bukowy B, Elliott $R R D$, et al. Lung-protective ventilation for the surgical patient: international expert panel-based consensus recommendations. $\mathrm{Br}$ J Anaesth 2019;123:898-913.

44. Arnal JM, Garnero A, Saoli M, Chatburn RL. Parameters for Simulation of Adult Subjects During Mechanical Ventilation. Respiratory Care 2018;63:158-68. 